\section{Seed storage, temperature and relative humidity}

I have read with interest the recent correspondence between the groups at Reading, UK (Ellis et al, 1991), and Fort Collıns, USA (Vertuceı and Roos, 1991), regarding seed moisture content, storage, viability and vigour (Seed Sclence Research 1, 275-279)

The differences raised by this correspondence have major implications for seed bank storage of crop and, particularly, short-lived wild species Many seed banks currently dry seeds to equilibrium with $15 \%$ relative humidity at $15^{\circ} \mathrm{C}$ and then place them in comparatively air-tight packaging before long-term storage at $-20^{\circ} \mathrm{C}$ These conditions have been recommended by the International Board for Plant Genetic Resources (see Cromarty et al, 1985)

It is thus important to reconcile the arguments presented by the two groups if long-term seed conservation is to proceed on a firm basis

Ellis et al at Reading University carry out the accelerated ageing of seed in a closed contanner, where the two components of interest are air and seed Each seed sample has been adjusted to a known morsture content The accelerated ageing of such samples is carried out at a range of temperatures By adjustıng the moisture content of the seeds, sealıng them in a container and then altering the temperature, the protocol mimics usual seed bank practice

Vertucci and Roos (1990) at the National Seed Storage Laboratory, Fort Collıns, age seeds under an experimental regimen that involves a sealed system comprising three components air, seed and a saturated salt solution Specific saturated salt solutions are chosen to control the $\mathrm{RH}$ of the air to a given value at the temperature of the agenng treatment Each solution acts as a reservorr either giving out or takıng up water vapour untıl the air, and hence the seed, is fully in equilibrium, akın to that expected in an open system Using this method, seed storage life can be sensibly linked to relative humıdity

In the 'two-component' system, the properties of the air trapped within the container on sealing will alter as the temperature is raised (as in accelerated ageing) or lowered (as in seed bank storage) By inspection of the isotherms presented by Vertucci and Roos (1991, Fig 2), it is possible to obtain approximate readings for equilibrium moisture contents of soyabean seed at $10 \% \mathrm{RH}$ at 25 and $35^{\circ} \mathrm{C}$, these values are about 45 and $35 \%$ (dry weight basıs), respectively Using a psychrometric chart (Chartered Institute of Building Services, 1978), it is possible to determıne the moisture content and specific volume of the air in the above two environmental conditions, given a standard barometric pressure of $101325 \mathrm{kPa}$ The values are about 00020 and $00037 \mathrm{~kg}$ of water $\mathrm{kg}^{-1}$ of dry dir occupying 0848 and $0878 \mathrm{~m}^{3} \mathrm{~kg}^{-1}$ of dry air, respectıvely Assuming that $100 \mathrm{~g}$ dry weight of soyabean seed has been fully equilibrated with air at $10 \% \mathrm{RH}$ and $25^{\circ} \mathrm{C}$, before being sealed into a contanner for accelerated ageing at $35^{\circ} \mathrm{C}$, the volume of air that must be sealed in the container to maintain the $10 \% \mathrm{RH}$ equilibrium at the higher temperature, when predicted from Vertucc and Roos, can be calculated as near to $05 \mathrm{~m}^{3}$ Similar calculations to model the situation where the temperature of the sealed container is reduced to $15^{\circ} \mathrm{C}$ give a value of $07 \mathrm{~m}^{3}$ Even bearing in mind increased total pressure inside the container and the effect of changing seed volume, a ratio of air volume seed weight of this magnitude will never be encountered in accelerated ageing experiments Thus, direct comparison of the 'two-component' with the 'threecomponent' protocol appears to be invalid This is further borne out by the fact that, when the container is sealed, the total moisture present is fixed Table 1 shows the moisture that might be sealed into a container at the start of an ageing treatment For soyabean seeds to stay in equilibrium when moved from $35^{\circ} \mathrm{C}$ to $25^{\circ} \mathrm{C}$, an extra $1 \mathrm{~g}$ of water would be required by the seed This is clearly not avallable from the air

Prediction of the equilibrium within the 'twocomponent' system, once the temperature has been changed, is difficult Inevitably, the equilibrium will be influenced by the ratio of the water-carrying capacity of the air to that of the seed (air volume seed weight) When there is limited air in the container (which should be current practice in accelerated ageing experiments and seed bank storage), the seed moisture content can vary little as the temperature is raised or lowered after sealıng Similarly, it seems unlikely that the water 'coverage' could also change Consequently, the four separate sorption isotherms for soyabean presented by Vertucci and Roos (1991, Fig 2) will approach that of a single isotherm, if the most extreme situation pertaining in the 'twocomponent' system is represented The position of this isotherm will be influenced by the temperature at which the seeds were equilibrated to a set moisture content, before sealıng and then accelerated ageıng This being so, the Van't Hoff analysis shown by Vertucc and Roos (1991, Fig 3) is likely to have a slope near to zero for each 'two-component' moisture content The intercept on the $\mathrm{RH}$ axis would be influenced by the equilibrium temperature The impli- 
Table 1 Total moisture in a 'two-component' seed ageıng regımen

\begin{tabular}{lccccc}
\hline $\begin{array}{l}\text { Temperature } \\
\left({ }^{\circ} \mathrm{C}\right)\end{array}$ & $\begin{array}{c}\text { RH } \\
\text { of air } \\
(\%)\end{array}$ & $\begin{array}{c}\text { Predicted } \\
\text { equilibrium } \\
\text { moisture } \\
\text { content } \\
\text { (dry basis, } \%)\end{array}$ & $\begin{array}{c}\text { Weight of } \\
\text { water } \\
\text { associated } \\
\text { with } 100 \mathrm{~g} \\
\text { dry weight } \\
(\mathrm{g})\end{array}$ & $\begin{array}{c}\text { Weight of } \\
\text { water in } \\
100 \mathrm{~cm}^{3} \text { of } \\
\text { air at } \\
\text { equilibrium } \\
\left(\mathrm{g} \times 10^{4}\right)\end{array}$ & $\begin{array}{c}\text { Total weight } \\
\text { of water in } \\
\text { container } \\
(\mathrm{g})\end{array}$ \\
\hline 5 & 10 & 65 & 65 & 06 & 650006 \\
15 & 10 & 53 & 53 & 13 & 530013 \\
25 & 10 & 45 & 45 & 26 & 450026 \\
35 & 10 & 35 & 35 & 42 & 350042 \\
\hline
\end{tabular}

Data extrapolated from Vertucc \& Roos (1991) for soyabean, $100 \mathrm{~g}$ of seeds occupy ca $140 \mathrm{~cm}^{3}$ and number ca 2500 seeds, from direct observation, a foll bag containıng $100 \mathrm{~g}$ of seed contains $<100 \mathrm{~cm}^{3}$ of air

cation of this must be that, under the conditions discussed by Vertucci and Roos (1991), at $65^{\circ} \mathrm{C}$ the lowest safe RH is much less than the $25 \% \mathrm{RH}$ recommended by them from their work on a threecomponent' system and closer to that extrapolated by Ellis et al (1990)

It would therefore appear that the 'threecomponent' system is more satisfactory for the elucidation of the biophysics of seed storage, but that the 'two-component' system is more appropriate for modelling of current seed bank procedures What is needed is a bridge between the two approaches, based on a study of the partition of moisture in a "twocomponent' system

What then of the current advice to those involved with seed banks? Vertuccl and Roos (1991) suggest that a conservative approach is taken when definıng the ideal conditions for long-term seed storage in $e x$ situ conservation This is a sentiment with which no one could disagree Yet they give no indication of the practical consequences of adopting their advice (1 e an RH of $25 \%$ ) compared with that of Cromarty et al $\left(1985\right.$, an $\mathrm{RH}$ of $10-15 \%$ at $\left.15^{\circ} \mathrm{C}\right)$ or Ellis et al (1990, RH down to $106 \%$ ) From my earher arguments, this can now be justifiably calculated using the viability equations developed by Ellis and Roberts (1980), provided that

(1) the seeds are first held under conditions where equilıbrium akın to an open system will be achieved,

(2) the seeds are then sealed into a container so that the enclosed air volume is small in relation to the seed weight, and

(3) the equilibrium moisture content is used to define the water status of the seeds for use in the viability equations so that seed storage behaviour under the new temperature conditions may be estımated

Table 2 shows the estimated rates of loss of seed viability predicted to occur when an example of a wild species (with comparatively short-lived seeds) and a cultivated species are stored in a gene bank at $-20^{\circ} \mathrm{C}$. having first been equilibrated at the optımal RH values recommended by Vertucc and Roos (1991), Cromarty et al (1985) and Ellis et al (1990) Equilibrium moisture contents were interpolated from the soyabean 1sotherms presented by Vertucc and Roos (1991, Fig 2) and an unpublished $21^{\circ} \mathrm{C}$ 1sotherm for Acer platanoides (J B Dickie, personal communication)

Clearly, for crop species such as soyabean, adopting a conservative approach will be acceptable in practice for the 20 years that Vertucci and Roos think it will take finally to resolve the true optımum dryıng RH This advice will be even more acceptable if the collections are of high initial quality For wild species such as Acer platanoides, this conservative advice seems impractical Work at Wakehurst Place has examined the seed storage behaviour of Ulmus carpinIfolla at 36, 42 and $52^{\circ} \mathrm{C}$ (Tompsett, 1986), Acer platanoides at $52^{\circ} \mathrm{C}$ (Dickıe et al, 1991) and Malus domestica at 42 and $62^{\circ} \mathrm{C}$ (Dickie, 1988) at moisture contents in equilibrium with RH values lower than those advised by Vertucci and Roos and at least as low as those recommended by Cromarty et al (1985) All these species showed reduced rates of viability loss under such conditions and no difficulties with germination were noted From Table 2, adoptıng advice given by Vertucci and Roos, rather than the current IBPGR standard (Cromarty et al, 1985), can be seen to double roughly the rate of loss of viability in both species Large losses of viability would be expected in seed collections of species such as $A$ platanoides within the 20 years proposed for the resolution of this problem

What then of the recommendations by Ellis et al (1990)? While Hong et al (1990) maintain that $A$ platanotdes seeds can be dried successfully to moisture contents as low as $4 \%$ fresh weight basis (fwb), $1 \mathrm{e}$ in equilibrium with $\mathrm{RH}$ values as low as $106 \%$, Dickie et al (1990) found that viability is greatly reduced if seeds are dried below the IBPGR 
Table 2 Moisture content and longevity of seeds of Glycine max (L) Merr and Acer platanoides $\mathrm{L}$

\begin{tabular}{|c|c|c|c|}
\hline Equilibrium to & $\begin{array}{c}21^{\circ} \mathrm{C} \\
11 \% \mathrm{RH}\end{array}$ & $\begin{array}{c}21^{\circ} \mathrm{C} \\
15 \% \mathrm{RH}\end{array}$ & $\begin{array}{c}21^{\circ} \mathrm{C} \\
25 \% \mathrm{RH}\end{array}$ \\
\hline $\begin{array}{l}\text { Safe value for RH } \\
\text { given by }\end{array}$ & $\begin{array}{l}\text { Ellis et al } \\
\quad(1990)\end{array}$ & $\begin{array}{l}\text { Cromarty et al } \\
(1985)\end{array}$ & $\begin{array}{c}\text { Vertuccl \& Roos } \\
\text { (1991) }\end{array}$ \\
\hline \multicolumn{4}{|c|}{ Moisture content* $(\%$, fresh wt basis $)$} \\
\hline$G \max$ & 46 & 49 & 59 \\
\hline A platanoides & 53 & 65 & 75 \\
\hline \multicolumn{4}{|c|}{ Time taken for viability to fall from 977 to $841 \%$ at $-20^{\circ} \mathrm{C}$ (years) } \\
\hline$G \max$ & 5255 & 4059 & 190 I \\
\hline A platanoldes & 1148 & 484 & 264 \\
\hline
\end{tabular}

*Obtained from isotherms produced from experimental data

†Predicted using viability equations from Dickie et al (1990) for $G$ max and from Dickie et al (1991) for $A$ platanoides

recommended conditions of $15 \% \mathrm{RH}$ at $15^{\circ} \mathrm{C}$ Seeds of Ulmus carpinifolia and $M$ domestica, on the other hand, showed improved storage that of $M$ domestica reachıng acceptable lifespans for gene bank practice while that for $U$ carpinifolia was only just acceptable However, Tompsett (1986) observed that for $U$ carpinifolia the logarithmic relationship between rate of loss of viability and moisture content continued down to a value as low as $33 \%$ (fwb) At this moisture content, there is a predicted threefold increase in life span over that predicted for storage at a moisture content in equilibrium with conditions recommended by Ellis et al At $21^{\circ} \mathrm{C}$, direct measurement by dew point hygrometry of the air equilibrated with $U$ carpinifolia seeds at $33 \%$ moisture content (fwb) gave a value of $6 \%$ RH (P B Tompsett, personal communication) This is well below that reported by Elhs et al (1990) to be the common critical value for many crops

The challenges of $e x$ situ seed conservation of plant biodiversity (sensu lato) therefore appear more demanding than for crops, in that their inherent longevities are not as great and their longevity responses to drying are not as uniform Thankfully, in contrast, earlier work on the effects of temperature on storage suggests some common behaviour with crops (Dickie et al, 1990) None the less, storage lives of sufficient duration appear possible under seed bank conditions The goal of successful $e x$ situ conservation of biodiversity is practical even for a species with short inherent seed longevity, such as Acer platanoides, particularly if seeds of high viability are placed in store Whether a single universal optimal drying regimen for long-term storage can be found remains to be seen Whether we have 20 years in which to find it is even less certain

What is clear is the need for those involved in plant biodiversity conservation to be able to identify rapidly the appropriate and optımal seed water status for long-term seed storage and the temperature and
RH conditions under which this will be achieved, without entering into detalled seed viability exper1ments In this respect, I support the suggestion that seed water potentials and hence air equilibrium $\mathrm{RH}$ values are more likely to yield a unifying principle than seed moisture contents However, the determination of air RH is not without technical difficulty, the accuracy of the determination being much more dependent upon the equipment used than is the gravimetric determination of seed moisture content

So far in this discussion, three methods of determinıng equilibrium $\mathrm{RH}$ have been used and the results have been compared without consideration of the methods used

(1) the passive (and assumptive) method involving equilibrium of seeds to constant weight above a solution maintaining a constant RH (Anonymous, 1960) used at Fort Collins, the proper use of such solutions is surrounded by caveats on how the salt solutions are saturated, the volume of air which can be controlled, the control of temperature and the contamination of the solution leading to loss of control,

(2) the use of a Novasina Humidat-IC 1 instrument, as at Reading University The sensor secondarily measures the changes in electrolytic capacity and these are closely correlated with changes in $\mathrm{RH}$ These machines are themselves calıbrated using saturated salt solutions The accuracy of the Novasina Humidat-IC 1 instrument given by the manufacturer's literature is $\pm 2 \% \mathrm{RH}$ over the range $10-100 \% \mathrm{RH}$, and

(3) the use of a Michell 4020 cooled mirror dew point hygrometer, as at Wakehurst Place A mirror is cooled until the water in the adjacent air condenses upon its surface This dew point is recorded to an accuracy of $\pm 02^{\circ} \mathrm{C}$ over the range of dew point from $-48^{\circ} \mathrm{C}$ to ambient temperature and is traceable against a national standard 
Accuracy of determining critical RH values when $<10 \%$ is thus difficult unless the appropriate equipment is used The unusual isotherms presented by Ellis et al (1990), which turn down sharply at $10 \%$ RH may be a consequence of this

The accuracy of measurement of each approach varies such that direct comparison of the values from each is at best tenuous and at worst misleading A detailed discussion of these variations and how they might be overcome by calibration to a traceable international standard, is presented by Pragnell (1988)

To some, this call for accurate and repeatable specification of RH values may appear unnecessary and pedantic In practice, it is the difference between successful conservation and failure At the low values of RH being discussed, small changes in RH lead to large changes in seed water potential In $U$ carpinifolia, at least these give the large increases in seed longevity necessary to achieve worthwhile conservation These small differences in $\mathrm{RH}$ could easily get lost in the technical difficulties of measurement Imprecise specification at the research stage must also make the successful application of the work more difficult in practice Controlling seed drying environments to known stable values of temperature and $\mathrm{RH}$ is difficult enough without having to guess what the real experimental values were'

(I thank my colleagues at Wakehurst Place for their interest, many helpful suggestions and unpublished data )

\section{References}

Anonymous (1960) Saturated solutions for the control of humidity in biological research Ecology 41, 232-236

Chartered Institution of Bulding Services (1978) (CIBS, Delta House, 222 Balham High Road, London SW12 9BS ) Psychrometric chart for drv-bulb temperatures $-10^{\circ} \mathrm{C}$ to $60^{\circ} \mathrm{C}$

Cromarty, A S, Ellıs, R H and Roberts, E.H (1985) The design of seed storage facllities for genetic conservation IBPGR, Rome

Dickıe, J.B (1988) Prospects for the long-term storage of apple seeds Veroffentlichungen der LandwirtschaftlichChemischen Bundesanstalt Linz/Donau 19, 47-63

Dickıe, J B., Elıs, R.G., Kraak, H L, Ryder, $K$ and Tompsett, P.B (1990) Temperature and seed storage longevity Annals of Botany 65, 197-204

Dıckıe, J.B., May, K, Morrıs, S.V A and Titley, S E (1991) The effects of desiccation on seed survival in Acer platanoldes $\mathrm{L}$ and Acer pseudoplatanus $\mathrm{L}$ Seed Science Research 1, 149-162

Ellis, R.H and Roberts, E H (1980) Improved equations for the prediction of seed longevity Annals of Botany 45, 13-30

Ellıs, R.H , Hong, T D., Roberts, E.H and Tao, K-L (1990) Low-moisture-content limits to relations between seed longevity and moisture Annals of Botany 65, 493-504

Ellss, R.H., Hong, T.D. and Roberts, E H (1991) Seed moisture content, storage, viability and vigour (correspondence) Seed Sclence Research 1, 275-277

Hong, T.D and Ellis, R.H (1990) A comparison of maturation dryıng, germination and desiccation tolerance between seeds of Acer pseudoplatanus $\mathrm{L}$ and Acer platanoides L New Phytologist 116, 589-596

Pragnell, R F (1988) The relationship between humidity calibration standards and standards for environmental testıng Environmental Engineering 1, Part 1, 13-16

Tompsett, P.B (1986) The effect of temperature and moisture content on the longevity of seed of Ulmus carpmifolia and Terminalia brassu Annals of Botanv 57. $875-883$

Vertucc, C.W and Roos, E E (1990) Theoretical basis of protocols for seed storage Plant Physiology 941019 1023

Vertucc, C W and Roos, E.E (1991) Seed moisture content. storage, viability and vigour (correspondence) Seed Sclence Research 1, 277-279

R.D. Smith

Royal Botanıc Gardens, Kew, Wakehurst Place, Ardingly, West Sussex, RH17 6TN, UK

¿ Royal Botanic Gardens, Kew, 1992 